JIPS, Vol. 2 No. 1

Halaman: 90 - 104

Mei 2021
Jurnal Inovasi Pembelajaran di Sekolah

DOI: https://doi.org/10.51874/jips.v1i01.8

ISSN 2774-9363 (Cetak)

ISSN 2774-9746 (Online)
Jurnal Inovasi Pembelajaran di

Sekolah

\title{
Peningkatan Hasil Belajar Daring PJOK Masa Pandemi Covid-19 melalui Model Classroom pada Peserta Didik Kelas V SD Negeri Bugangan 03 Kota Semarang
}

\author{
Sudarsono \\ SD Negeri Bugangan 03 Kota Semarang
}

\begin{abstract}
Abstrak
Penelitian ini bertujuan untuk mengetahui hasil belajar Pembelajaran daring PJOK dengan menggunakan model classroom pada peserta didik kelas V SD Negeri Bugangan 03 dan hasil kerjasama antara peserta didik dengan lingkungan keluaraga pada pembelajaran daring PJOK. Metode yang digunakan yaitu metode penelitian tindakan kelas dan data yang digunakan menggunakan pembelajaran daring dengan menggunakan media classroom . Populasi dalam penelitian ini yaitu siswa Kelas V SD Negeri Bugangan 03 Kecamatan Semarang Timur Kota Semarang. Pengambilan sampel dalam penelitian ini adalah Siswa Kelas V SD Negeri Bugangan 03 Kecamatan Semarang Timur Kota Semarang .dengan jumlah 37 siswa. Instrumen yang digunakan dalam penelitian ini adalah hasil belajar pembelajaran daring PJOK dengan menggunakan media classroom. Hasil dari penelitian ini menunjukan bahwa Hasil Belajar siswa SD Negeri Bugangan 03 Kecamatan Semarang Timur Kota Semarang pada siklus I rata rata nilai $71 \%$ sedangkan nilai tertinggi 12,75\% dengan jumlah ketuntasan hasil belajar sebanyak 20 peserta didik, siklus II rata rata nilai 73\% sedangkan nilai tertinggi 13,5\% dengan jumlah ketuntasan hasil belajar sebanyak 28 peserta didik. Berdasarkan penelitian ini direkomendasikan agar guru PJOK lebih menonjolkan nilai karakter peserta didik dalam mengkondisikan anggota keluarga agar lebih banyak terlibat dan perencanaan pembelajaran daring ini agar dipersiapkan sesuai dengan materi yang akan diajarkan.
\end{abstract}

Kata Kunci: media classroom, hasil belajar

Abstract

This study aims to determine the learning outcomes of online learning in PJOK using the classroom model in class V SD Negeri Bugangan 03 and the results of collaboration between students and the family environment in online learning PJOK. The method used is the classroom action research method and the data used is online learning using classroom media. The population in this study were fifth grade students of SD Negeri Bugangan 03, East Semarang District, Semarang City. The samples in this study were the fifth grade students of SD Negeri Bugangan 03, East Semarang District, Semarang City, with a total of 37 students. The instrument used in this study was the learning outcomes of PJOK online learning using classroom media. The results of this study indicate that the students' learning outcomes of SD Negeri Bugangan 03, East Semarang District, Semarang City in the first cycle have an average value of $71 \%$ while the highest value is $12.75 \%$ with the total completeness of learning outcomes as many as 20 students, cycle II an average value of $73 \%$ while the highest score was $13.5 \%$ with the total number of learning outcomes as many as 28 students. Based on this research, it is recommended that PJOK teachers emphasize the character values of students in conditioning family members to be more involved and planning online learning so that they are prepared according to the material to be taught.

Keywords: classroom media, learning outcomes

\section{PENDAHULUAN}

Menurut UU No. 20 Tahun 2003 tentang Sistem Pendidikan Nasional Bab I Pasal 1 (ayat 1), pendidikan pada dasarnya merupakan usaha sadar dan terencana untuk mewujudkan suasana belajar dan proses pembelajaran agar peserta didik secara aktif mengembangkan potensi dirinya untuk memiliki 
kekuatan spiritual keagamaan, pengendalian diri, kepribadian, kecerdasan, akhlak mulia, serta keterampilan yang diperlukan dirinya, masyarakat, bangsa, dan negara. Di dunia saat ini sedang marak wabah coronavirus yang dapat menyebabkan penyakit yang disebut covid-19.

Covid-19 yang terjadi di berbagai negara termasuk Indonesia berdampak pada berbagai bidang termasuk pendidikan. Saat ini dunia pendidikan sedang menghadapi permasalahan yang cukup kompleks. Serangan virus tersebut berdampak pada penyelenggaraan pembelajaran di semuajenjang pendidikan. Tentunya tidak ada banyak kendala pada jenjang perguruan tinggi dan sebagian sekolah menengah yang sudah terbiasa menerapkan pembelajaran online, namun tidak demikian dengan jenjang pendidikan dasar (sekolah dasar) yang bahkan tidak diperbolehkan membawa perangkat komunikasi (handphone) ke sekolah atau ke ruang kelas.

Menteri Pendidikan dan Kebudayaan Republik Indonesia mengeluarkan Surat Edaran Nomor 4 tahun 2020 tentang pelaksanaan kebijakan pendidikan dalam masa darurat penyebaran covid-19. Proses belajar dilaksanakan di rumah melalui pembelajaran daring/jarak jauh yang bertujuan untuk memutus mata rantai penyebaran covid-19. Pembelajaran daring merupakan pemanfaatan jaringan internet dalam proses pembelajaran. Pembelajaran daring membuat siswa memiliki keleluasaan waktu belajar, dapat belajar kapanpun dan dimanapun. Siswa dapat berinteraksi dengan guru menggunakan beberapa aplikasi seperti classroom, video converence, telepon atau live chat, zoom maupun melalui whatsapp group. Pembelajaran ini merupakan inovasi pendidikan untuk menjawab tantangan akan ketersediaan sumber belajar yang variatif. (Nakayama M, Yamamoto H, 2007: 200).

Pandemi covid-19 yang terjadi di Indonesia sangat mempengaruhi kegiatan belajar mengajar di sekolah dasar, sehingga kegiatan belajar mengajar yang awalnya dilakukan dengan bertatap muka langsung di kelas harus beralih dengan pembelajaran secara daring atau jarak jauh. Hal ini tentu saja memberikan dampak pada pembelajaran PJOK di SD Negeri Bugangan 03 diantaranya pembelajaran PJOK yang tidak dapat terlaksana tatap muka, Hal ini berpengaruh dengan pola pikir guru PJOK dengan peserta didik dimana pembelajaran dialihkan dengan sistem daring. Permasalahan yang tampak adalah model pembelajaran yang menyesuaikan kebutuhan kondisi pada kuota internet peserta didik.

Pembelajaran daring PJOK ini juga merubah dministrasi guru yang awalnya tatap muka disesuaikan dengan masa pandemi covid-19, disamping protokol kesehatan juga keselamatan dalam mengerjakan tugas berupa gerakan fisik. Permasalahan selanjuttnya adalah piranti handphone peserta didik kebanyakan belum punya dan mengandalkan milik orangtua. Kerjasama guru PJOK dengan orangtua terhambat karena permasalahan pekerjaan sehingga tugas yang diberikan kepada peserta didik banyak yang tidak dikerjakan.

Peneliti yang juga sebagai guru PJOK SD Negeri Bugangan 03 mempunyai inisiatif untuk membuat model pembelajaran daring berupa classroom. Ssehingga penelitian ini untuk mengatasi permasalahan 
diatas mengambil judul "Peningkatan Hasil Belajar Daring PJOK Masa Pandemi Covid-19 Melalui Model Classroom Pada Peserta Didik Kelas V SD Negeri Bugangan 03 Kota Semarang”.

\section{KAJIAN PUSTAKA}

\section{Hakikat Pembelajaran PJOK}

Pengertian Pembelajaran Berbicara mengenai pembelajaran adalah bicara tentang sesuatu yang tidak pernah berakhir sejak manusia ada dan berkembang di muka bumi sampai akhir jaman nanti. Menurut Hamalik (2017: 57) pembelajaran adalah suatu kombinasi yang tersusun meliputi unsur-unsur manusiawi, material, fasilitas, perlengkapan, dan prosedur yang saling mempengaruhi mencapai tujuan pembelajaran.

Menurut Mulyasa (2002: 24) pembelajaran adalah proses interaksi antar siswa dengan lingkungannya sehingga terjadi perubahan prilaku ke arah yang lebih baik. Menurut Aris Fajar Pambudi (2014: 50) suatu proses pembelajaran dikatakan berhasil apabila dalam diri sebagian besar hingga seluruh peserta didik mengalami perubahan perilaku yang positif. Sagala (2010: 61) mengatakan bahwa pembelajaran adalah membelajarkan siswa menggunakan asas pendidikan maupun teori belajar merupakan penentu utama keberhasilan pendidikan. Berdasarkan uraian tersebut dapat disimpulkan bahwa pembelajaran adalah usaha sadar dari guru membuat siswa belajar, yaitu terjadinya tingkah laku pada siswa yang belajar, dimana perubahan itu dengan didapaannya kemampuan baru dan karena ada adanya usaha.

\section{Pendidikan Jasmani Olahraga dan Kesehatan}

Pendidikan jasmani mengandung makna bahwa mata pelajaran ini menggunakan aktivitas jasmani sebagai media untuk mencapai tujuan aktivitas pembelajaran yang direncanakan, yang bertujuan untuk meningkatkan kebugaran jasmani individu. Pendidikan jasmani olahraga dan kesehatan di sekolah merupakan dasar yang baik bagi perkembangan olagraga di luar sekolah. Menurut Saryono \& Rithaudin (2011: 146) pendidikan jasmani adalah proses pendidikan yang memanfaatkan aktivitas jasmani yang di rencanakan secara sistematik yang bertujuan untuk meningkatkan individu secara organik, neuromuskuler, perseptual, kognitif dan emosional.

Rahayu (2013: 3) mengemukakan bahwa pendidikan jasmani adalah fase dari program pendidikan keseluruhan yang memberikan kontribusi, terutama melalui pengalaman gerak, untuk pertumbuhan dan perkembangan secara utuh untuk tiap siswa. Pendidikan jasmani didefinisikan sebagai pendidikan dan melalui gerak dan harus dilaksanakan dengan cara cara yang tepat agar memiliki makna bagi siswa. Pendidikan jasmani merupakan program pembelajaran yang memberikan perhatian yang proporsional dan memadai pada domain-domain pembelajaran, yaitu psikomotor, kognitif, dan afektif. 
Menurut Bandi Utama (2011: 2) pendidikan jasmani merupakan bagian yang tidak biasa terpisahkan dari pendidikan pada umumnya. Pendidikan jasmani mempengaruhi peserta didik dalam hal kognitif, afektif, dan psikomotor melalui aktivitas jasmani. Berdasarkan uraian di atas dapat disimpulkan bahwa Pendidikan Jasmani Olahraga dan Kesekatan (PJOK) merupakan bagian dari sistem pendidikan secara menyeluruh yang memanfaatkan aktivitas jasmani yang bertujuan untuk meningkatkan kemampuan individu mencakup semua aspek baik organik, motorik, kognitif maupun afektif.

\section{Pembelajaran Daring}

Pengertian Pembelajaran daring adalah pembelajaran merupakan pembelajaran yang dilakukan secara online, menggunakan aplikasi pembelajaran maupun jejaring social. Pembelajaran daring merupakan program penyelenggaraan kelas pembelajaran dalam jaringan untuk menjangkau kelompok target yang masif dan luas. Melalui jaringan, pembelajaran dapat diselenggarakan secara masif dengan peserta yang tidak terbatas (Bilfaqih, Yusuf dan M. Nur Qomarudin, 2015: 1).

Pembelajaran daring dapat menggunakan teknologi digital seperti google classroom, rumah belajar, video converence, telepon atau live chat, zoom, whatsapp group dan lainnya (Dewi, 2020: 58). Definisi umum dari e-learning atau pembelajaran daring menurut Gilbert \& Jones (2001) yaitu: pengiriman materi pembelajaran melalui suatu media elektronik seperti internet, intranet/extranet, satellite broadcast, audio/video tape, interactive TV, CD-ROM, dan computer-based training (CBT). The ILRT of Bristol University (2005) mendefinisikan e-learning sebagai penggunaan teknologi elektronik untuk mengirim, mendukung, dan meningkatkan pengajaran, pembelajaran dan penilaian.

Menurut Khan (2005), e-learning menunjuk pada pengiriman materi pembelajaran kepada siapapun, dimanapun, dan kapanpun. E-Learning dilakukan menggunakan berbagai teknologi dalam lingkungan pembelajaran yang terbuka, fleksibel, dan terdistribusi. Lebih jauh, istilah pembelajaran terbuka dan fleksibel merujuk pada kebebasan peserta didik dalam hal waktu, tempat, kecepatan, isi materi, gaya belajar, jenis evaluasi, belajar kolaborasi atau mandiri.

Tujuan Pembelajaran Daring Secara umum, pembelajaran daring bertujuan memberikan layanan pembelajaran bermutu secara dalam jaringan (daring) yang bersifat masif dan terbuka untuk menjangkau audiens yang lebih banyak dan lebih luas (Bilfaqih, Yusuf dan M. Nur Qomarudin, 2015: 4).

Manfaat Pembelajaran Daring Menurut Bilfaqih, Yusuf dan M. Nur Qomarudin (2015: 4)

a. Meningkatkan mutu pendidikan dan pelatihan dengan memanfaatkan multimedia secara efektif dalam pembelajaran.

b. Meningkatkan keterjangkauan pendidikan dan pelatihan yang bermutu melalui penyelenggaraan pembelajaran dalam jaringan. 
c. Menekan biaya penyelenggaraan pendidikan dan pelatihan yang bermutu melalui pemanfaatan sumber daya bersama.

Menurut Rohmah (2016: 12) manfaat e-learning yaitu

a. Dengan adanya e-learning maka dapat mempersingkat waktu pembelajaran dan membuat biaya studi lebih ekonomis

b. E-learning mempermudah interaksi antara peserta didik dengan bahan materi,

c. Peserta didik dapat saling berbagi informasi dan dapat mengakses bahanbahan belajar setiap saat dan berulang-ulang, dengan kondisi yang demikian itu peserta didik dapat lebih memantapkan penguasaannya terhadap materi pembelajaran

d. Dengan e-learning proses pengembangan pengetahuan tidak hanya terjadi di dalam ruangan kelas saja, tetapi dengan bantuan peralatan komputer dan jaringan, para siswa dapat secara aktif dilibatkan dalam proses belajarmengajar.

Menurut Riyadi (2014) manfaat e-learning adalah :

a. E-learning memberi fleksibilitas dalam memilih waktu dan tempat untuk mengakses perjalanan.

b. E-learning memberi kesempatan bagi pembelajar secara mandiri memegang kendali atas keberhasilan belajar.

c. E-learning memberi efisiensi biaya bagi administrasi penyelenggara, efisiensi penyediaan sarana dan fasilitas fisik untuk belajar dan efisiensi biaya bagi pembelajar adalah biaya transportasi dan akomodasi.

\section{Pelaksanaan Pembelajaran Media Classroom}

1) Pengertian Pembelajaran

Kata pembelajaran berasal dari kata dasar "belajar" yang berarti suatu proses yang ditandai dengan perubahan pada diri seseorang. Perubahan sebagai hasil dari proses belajar dapat ditunjukkan dalam berbagai bentuk perubahan pengetahuan, pemahaman, sikap dan tingkah laku ketrampilan, kecakapan, kebiasaan, serta perubahan aspek-aspek lain yang ada pada diri individu yang sedang belajar (Sudjana, 2000: 28).

Pembelajaran menurut Thorndike terjadi melalui pembentukan asosiasi atau koneksi-koneksi antara pengalaman inderawi yakni persepsi terhadap stimulus atau peristiwa dan impuls-impuls saraf atau respon-respon yang memberikan manifestasinya dalam bentuk perilaku. Thorndike juga meyakini bahwa pembelajaran terjadi melalui rangkaian eksperimen trial and error atau menyeleksi dan mengoneksi (Nai, 2017: 102).

Pengertian-pengertian pembelajaran yang diutarakan para ahli mengutamakan kata kunci perubahan atau pengalaman. Dua kata kunci tersebut sangat dipengaruhi oleh arus pemikiran kaum Behavioral 
dalam memberi batasan tentang belajar dan pembelajaran yang merupakan dua sisi yang tak terpisahkan. Perubahan dan pengalaman dimaknai sebagai hakekat pembelajaran.

Batasan agak berbeda adalah yang dirumuskan dengan menggunakan kata kunci upaya yang mengindikasikan adanya pihak lain. Atau mekanisme lain yang harus ada seiring terjadinya proses belajar siswa. Mekanisme tersebut adalah guru, media, serta berbagai sumber, baik cetak maupun elektronik yang kemudian menjadi prasyarat belajar dan pembelajaran, sehingga batasan pembelajaran menjadi lebih sistematis jika dibahas melalui istilah teknologi pembelajaran (Nai, 2017: 122).

Berdasarkan definisi diatas penulis menyimpulkan bahwa pembelajaran merupakan suatu kegiatan yang memungkinkan didalamnya terdapat interaksi antara pendidik dan peserta didik sehingga terjadi aktivitas belajar.

2) Pelaksanaan Pembelajaran

Pelaksanaan pembelajaran adalah proses yang diatur sedemikian rupa menurut langkah-langkah tertentu agar pelaksanaan mencapai hasil yang diharapkan (Sudjana, 2010: 136).

Menurut Bahri \& Zain (2010: 1) Pelaksanaan pembelajaran adalah suatu kegiatan yang bernilai edukatif, nilai edukatif mewarnai interaksi yang terjadi antara guru dan siswa. Interaksi yang bernilai edukatif dikarenakan pelaksanaan pembelajaran yang dilakukan diarahkan untuk mencapai tujuan tertentu yang telah dirumuskan sebelum pelaksanaan pembelajaran dimulai.

Dengan pelaksanaan pembelajaran guru melakukan beberapa tahap pelaksanaan pembelajaran antara lain:

a) Membuka Pelajaran

Kegiatan membuka pelajaran adalah kegiatan yang dilakukan oleh guru untuk menciptakan suasana pembelajaran yang memungkinkan siswa siap secara mental untuk mengikuti kegiatan pembelajaran.

b) Penyampaikan Materi

Pembelajaran Menyampaikan materi pembelajaran merupakan inti dari suatu proses pelaksanaan pembelajaran. Dalam penyampaian materi guru menyampaikan materi berurutan dari materi yang paling mudah terlebih dahulu, untuk memaksimalkan penerimaan siswa terhadap materi yang disampaikan guru maka guru menggunakan metode yang mengajar yang sesuai dengan materi dan menggunakan media sebagai alat bantu penyampaian materi pembelajaran.

c) Menutup Pembelajaran

Kegiatan menutup pelajaran adalah kegiatan yang dilakukan guru untuk mengakhiri kegiatan inti pembelajaran. Dalam kegiatan ini guru melakukan evaluasi terhadap materi yang telah disampaikan. 


\section{3) Komponen Pelaksanaan}

Pembelajaran Belajar dan mengajar sebagai suatu proses sudah tentu harus dapat mengembangkan dan menjawab beberapa persoalan yang mendasar. Keempat persoalan (tujuan, bahan, metode, dan alat serta penilaian). Menjadi komponen utama yang harus dipenuhi dalam proses belajar-mengajar.

a) Tujuan

Tujuan dalam proses belajar-mengajar merupakan komponeen pertama yang harus ditetapkan dalam proses pengajaran yang berfungsi sebagai indikator keberhasilan pengajaran. Tujuan ini pada dasarnya adalah rumusan tingkah laku dan kemampuan yang harus dicapai dan dimiliki siswa setelah mereka menyelesaikan pengalaman dan kegiatan belajar dalam proses pengajaran (Sudjana, 2010: 63).

b) Bahan

Tujuan yang jelas dan oprasional dapat ditetapkan bahan pelajaran yang harus menjadi isi kegiatan belajar-mengajar. Bahan pelajaran inilah yang diharapkan dapat mewarnai tujuan, mendukung tercapai tujuan dan tingkah laku yang diharapkan untuk dimiliki siswa (Sudjana, 2010: 69).

c) Metode

Metode dan alat yang digunakan dalam pengajaran dipilih atas dasar tujuan dan bahan yang telah ditetapkan sebelumnya. Metode dan alat berfungsi sebagai jembatan atau media trasformasi pelajaran terhadap tujuan yang ingin dicapai (Sudjana, 2010: 77).

d) Alat

Alat peraga dalam mengajar memegang peranan penting untuk membantu menciptakan kegiatan belajar mengajar yang efektif. Sebab dengan adanya alat peraga, bahan yang akan disampaikan kepada siswa akan lebih mudah diterima dan dipahami (Sudjana, 2010: 104).

e) Penilaian

Untuk menetapakan apakah tujuan belajar telah tercapai atau tidak maka penilaianlah yang harus memainkan peran dan fungsinya. Dengan perkatan lain bahwa penilaian berperan sebagai barometer untuk mengukur tercapai tidaknya tujuan pembelajaran (Sudjana, 2010: 104).

\section{Media Classroom (Google classroom)}

Google classroom atau dalam bahasa Indonesia yaitu ruang kelas google adalah sebuah serambi pembelajaran yang dapat diperuntukan terhadap ruang lingkup pendidikan yang dimaksudkan untuk membantu menemukan jalan keluar atas kesulitan yang dialami dalam membuat penugasan tanpa menggunakan kertas (paperless) (Iskandar dkk, 2020: 144). 
Google classroom merupakan sebuah aplikasi yang memungkinkan terciptanya ruang kelas di dunia maya. Selain itu, google classroom juga menjadi sarana distribusi tugas, submit tugas bahkan menilai tugas-tugas yang dikumpulkan (Herman dalam Japar, 2020: 153).

Keefektifan pembelajaran dengan menggunakan google classroom dapat dilihat berdasarkan tingkat kesalahan yang dibuat oleh siswa saat menyelesaikan permaslahan yang diberikan, hal lain yang menjadi acuan keefektifan pembelajaran adalah pada saat guru memotivasi siswa untuk mempelajari materi yang telah diunggah ke dalam kelas google classroom (Iskandar dkk, 2020: 144).

Dengan demikian aplikasi ini dapat membantu pendidik dalam dan siswa dalam melaksanakan proses belajar yang lebih mendalam.

\section{Cara Penggunaan Google Classroom}

Dalam memulai menggunakan google classroom kita terlebih dahulu masuk ke akun google dan kemudian mencari produk google tersebut, setelah masuk pada akun google classroom kita dihadapakan pada tiga menu utama yaitu, stream (aliran), classwork (aktivitas siswa), dan people (orang). Stream adalah fasilitas google class untuk membuat pengumuman, mendiskusikan gagasan, atau melihat aliran tugas, materi, quiz dari topik-topik yang diajarkan guru.

Classwork dapat digunakan guru untuk membuat soal tes, pretes, quiz, mengunggah materi, dan mengadakan refleksi. Pada menu people guru dapat mengundang siswa dengan kode akses yang telah tersedia pada bilah people, sedangkan untuk mengundang guru lain sebagai kolaborator cukup dengan mengundang guru melalui email masing-masing. Materi yang diunggah pada bilah classwork dapat berupa file word, exel, powerpoint, pdf maupun video. Hal ini dilakukan guru untuk mengakomodasi adanya perbedaan terhadap kecapatan berpikir, latar belakang pengetahuan awal, dan perbedaan pada learning style peserta didik (Millatana dalam Iskandar dkk, 2020: 143).

a) Selain memberikan tugas, guru juga dapat menyampaikan penguman atau informasi terkait dengan mata pelajaran yang akan dipelajari oleh siswa di kelas nyata pada laman tersebut. Siswa dapat bertanya kepada guru ataupun kepada siswa lain dalam kelas tersebut terkait dengan informasi yang disampaikan oleh guru.

b) Siswa dapat melacak setiap tugas yang hampir mendekati batas waktu pengumpulan di laman Tugas, dan mulai mengerjakannya cukup dengan sekali klik.

c) Guru dapat melihat dengan cepat siapa saja yang belum menyelesaikan tugas, serta memberikan masukan dan nilai langsung di Kelas

\section{Gerak Dominan Senam Ketangkasan}

Olahraga senam membuat tubuh menjadi sehat dan bugar. Ada
beberapa jenis senam, salah $\quad$ satunya senam
olahraga pada awal pelajaran termasuk gerak dasar senam


Bagaimana gerak dominan senam ketangkasan? Sebelum membahas materi lebih mendalam.

a. Berlari dan Melompat

Melompat merupakan salah satu gerak dominan dalam senam ketangkasan. Melompat dilakukan dengan tumpuan satu kaki. Saat melakukan gerak melompat, gerakan dilakukan dengan awalan, melompat, dan mendarat. awalan gerak melompat dapat dilakukan dengan berlari. Kemudian, dilanjutkan dengan gerak bertumpu menggunakan satu kaki. Selanjutnya, tolak tubuh ke atas dan diakhiri dengan gerak mendarat dengan kedua kaki. Amati dan peragakan gerakan melompat seperti gambar berikut! endalam, lakukan kegiatan berikut.

b. Meloncat dan Menggantung

Sikap menggantung termasuk posisi statis. Menggantung dilakukan dengan menempatkan bahu di bawah alat. Latihan menggantung meningkatkan kekuatan dan daya tahan otot tangan. Teknik menggantung dilakukan dengan pegangan atas, dan pegangan bawah. Untuk berlatih menggantung, kam u perlu menyiapkan tongkat sepanjang $50 \mathrm{~cm}$.

c. Meloncat dan Mengayun

\begin{tabular}{llllllr}
\multicolumn{2}{c}{ Mengayun } & merupakan salah satu & gerakan & senam & ketangkasan. \\
Gerakan ini dapat & melatih kekuatan dan & kelenturan & ototmu. & Bagaimana \\
cara mengayun? & Keterampilan mengayun & dibentuk & dari & kemampuan
\end{tabular}
menggantung dan penguasaan teknik pegangan. Cara melakukan gerak mengayun sebagai berikut.

d. Berjalan Meniti

Berjalan meniti merupakan teknik berjalan di atas bangku atau balokkeseimbangan. Amati dan praktikkan gerakan meniti seperti Gambar 4.Bagaimana posisi tubuh dan tangan saat melakukan gerakan meniti? Apa fungsi gerakan meniti? Diskusikan bersama temanmu dan komunikasikan kepada gurumu.

\section{Menekuk dan Mendarat}

\begin{tabular}{rrrrrrr}
\multicolumn{2}{c}{ Istilah } & mendarat & merujuk & pada tindakan bertumpu di & atas & matras \\
atau tanah & setelah & melayang. & Gerakan mendarat dilakukan & dengan & kaki.
\end{tabular}
Kesalahan mendarat dapat menyebabkan cedera. Untuk menghindari cedera, berlatihlah gerakan mendarat secara tekun. Bagaimana gerakan mendarat yang benar? Peragakan gerakan mendarat dengan mengikuti langkah-langkah gerakan berikut. 
1) Tekuk lutut hingga membentuk sudut kurang dari $90^{\circ}$.

2) Gerakan mendarat dilakukan seperti orang hendak duduk di kursi.

3) Bagian kaki yang pertama kali mendarat ialah ujung telapak kaki, diikuti tumit dan persendian kaki, serta lutut dan punggung dibungkukkan.

4) Usahakan tumit tidak terangkat dari lantai saat mendarat.

Lakukan gerakan mendarat bersama temanmu secara bergantian. Amati dan bandingkan gerakanmu dan gerakan temanmu. Komunikasikan hasil pengamatanmu kepada gurumu secara santun. Apakah kamu mengalami kesulitan dalam melakukan gerakan mendarat? Jika kamu masih kesulitan, mintalah bimbingan gurumu.

\section{METODE PENELITIAN}

Pengertian Penelitian Tindakan Kelas (Clasroom Action Research) penelitian yang dilakukan oleh guru yang berfokus pada masalah yang ada di kelas yang bertujuan memperbaiki mutu praktik pelajaran di kelas.Penelitian Tindakan adalah jenis pendekatan riset criticalisme merupakan salah satu model penelitian yang menerapkan paradigma hasil penelitian tidak hanya berupa pengetahuan tetapi juga perubahan atau peningkatan mutu semua komponen yang diteliti.

Sedangkan Penelitian Tindakan Kelas (Classroom Action Research) adalah Penelitian tindakan yang dilakukan guru di kelas.PTK dilaksanakan demi perbaikan dan peningkatan praktik pembelajaran secara berkesinambunganTujuan PTK ialah pengembangan kemampuan-keterampilan guru untuk menghadapi permasalahan aktual pembelajaran di kelasnya dan atau di sekolahnya sendiri.Tujuan penyerta penelitian tindakan kelas ialah dapat ditumbuhkannya budaya meneliti dikalangan pendidik.

\section{Subjek dan Objek Penelitian}

Subjek penelitian yang terlibat dalam ujicoba penelitian tindakan adalah Pembelajaran daring PJOK menggunakan model classroom pada peserta didik 37 orang.

\section{Instrumen tes}

Alat ukur yang digunakan dalam penelitian ini adalah hasil belajar pembelajaran daring PJOK menggunakan model classroom yang digunakan dalam penelitian ini adalah pengembangan sendiri dengan mengacu pada metode atau prosedur yang sudah ditentukan. Prosedur yang dilakukan disesuaikan dengan tingkat kebutuhan yang diperlukan. 


\section{HASIL DAN PEMBAHASAN}

\section{Hasil}

\section{Siklus I}

Kegiatan yang dilakukan dalam tahap refleksi adalah menganalisanya jalannya pembelajaran dan menganalisis perangkat evaluasi pembelajaran daring PJOK menggunakan model classroom dengan materi pola gerak dominan pada senam ketangkasan. Berdasarkan perangkat evaluasi ditemukan beberapa kelemahan antara lain:

a) Media pembelajaran melalui PPt bentuk Video masih kurang mengena pada peserta didik tugas banyak yang kurang memahami.

b) Pada saat guru menjelaskan materi pembelajaran banyak peserta didik yang kurang memperhatikan instruksi guru/peneliti peserta didik kurang paham dengan materi atau tujuan dari pembelajaran tersebut hal ini ditunjukan dengan hasil dibawah ini

Berdasarkan hasil pengamatan dan respon pada siklus I diketahui bahwa hasil yang diperoleh belum memenuhi keinginan peneliti dalam pembelajaran daring PJOK menggunakan model classroom dengan materi pola gerak dominan pada senam ketangkasan maka pada refleksi peneli dan teman sejawat menganalisa kekurangan dan kelemahan guru terutama:

a) Bahan ajar guru harus lebih kreatif lagi terutama dalam kata perintah

b) Media pembelajaran yang dibuat terutama video durasi waktu untuk diperpendek tapi tidak mengurangi isi materi.

c) Peneliti harus mengetahui kesulitan peserta didik dalam memnbuka dan mengirim tugas melalui classroom.

d) Diskusi dan kerjasama antar peneliti dan guru senior diperkuat lagi, agar permasalahan segera teratasi.

Melihat hasil kinerja pada siklus I yang kurang memenuhi maka diperlukan perbaikan pada tindakan siklus II. Kelemahan dan kekurangan yang terjadi selama siklus I maka akan dicarikan solusi dan akan dilakukan perbaikan-perbaikan dalam melakukan siklus II.

\section{Siklus II}

Berdasarkan hasil penelitian Siklus II sebagaimana dipaparkan di atas, dapat dinyatakan hal-hal berikut:

a) RPP dan media dibuat secara paradigmatik yang sesuai dengan kaidah pengunaan materi pembelajaran daring PJOK menggunakan model classroom dengan materi pola gerak dominan.

b) Pelaksanaan sesuai dengan sistematika yang didasarkan kepada penerapan metode atau model pembelajaran tertentu. 
c) Hasil belajar peserta didik pembelajaran daring PJOK menggunakan model classroom dengan materi pola gerak dominan mengalami peningkatan.

\section{Pembahasan Hasil Penelitian}

Pengamatan pada siklus I dilakukan oleh peneliti dan teman guru sebagai teman sejawat pada kegiatan di dalam proses penelitian melalui lembar observasi. Pada observasi yang pengamat lakukan dalam proses kegiatan pembelajaran daring PJOK menggunakan model classroom dengan materi pola gerak dominan diperoleh temuan-temuan sebagai berikut :

a) Peneliti memberikan apersepsi hasilnya baik;

b) Penguasaan Peneliti terhadap materi hasilnya cukup;

c) Pengelolaan peserta didik hasilnya kurang karena banyak peserta didik yang belum paham dengan model classroom yang baru pertama kali digunakan oleh peerta didik.

d) Penggunaan media pembelajaran penelti yang kurang tepat pada peserta didik

e) Pemberian contoh melalui demonstrasi hasilnya kurang karena guru/peneliti masih menggunakan cara lewat kata kata atau verbalisme.

f) Bimbingan peneliti dibantu oleh peserta didik yang sudah bisa kepada peserta didik yang lainnya secara individu atau kelompok hasilnya kurang

Dilihat dari nilai hasil kegiatan pada siklus II perbaikan pembelajaran siklus II semua peserta didik kelas V SD Negeri Bugangan 03 Kota Semarang dapat melakukan kegiatan penelitian ini dengan hasil yang baik, dari 37 peserta didik yang melakukan penilaian pada penelitian ini sudah menunjukan kemampuan yang baik. Pada siklus II ini, peneliti berupaya agar terjadi peningkatan hasil pembelajaran daring PJOK menggunakan model classroom dengan materi pola gerak dominan dengan baik dan benar dengan mengacu pada kegiatan siklus I.

Sehingga penerapan kegiatan pembelajaran daring PJOK menggunakan model classroom dengan materi pola gerak dominan dalam penelitian dapat dioptimalkan kembali pada kegiatan pembelajaran selanjutnya. Perbaikan perangkat pembelajaran dan pencapaian indikator yang jelas peserta didik dapat melakukan instruksi guru/peneliti secara baik dan benar.

Tabel Hasil Evaluasi Siklus I

\begin{tabular}{|c|c|c|c|c|c|}
\hline \multirow[b]{2}{*}{ Hasil } & \multicolumn{4}{|c|}{ Kriteria Evaluasi Soal } & \multirow{2}{*}{$\begin{array}{c}\text { Rat } \\
\mathbf{a}\end{array}$} \\
\hline & Soal 1 & Soal 2 & Soal 3 & Soal 4 & \\
\hline 37 Siswa & 1,3 & 4,3 & 10 & 13 & 7,1 \\
\hline $\begin{array}{c}\text { Nilai } \\
\text { Maksimal }\end{array}$ & 10 & 20 & 30 & 40 & 100 \\
\hline Tertinggi & 2 & 10 & 18 & 24 & 13 \\
\hline
\end{tabular}




\begin{tabular}{|c|c|c|c|c|c|}
\hline Terendah & 0 & 0 & 3 & 4 & 2.5 \\
\hline Ketuntasan & \multicolumn{6}{|c|}{ 20 Peserta Didik } \\
\hline
\end{tabular}

\begin{tabular}{|c|c|c|c|c|c|}
\hline \multirow{2}{*}{ Hasil } & \multicolumn{4}{|c|}{ Kriteria Evaluasi Soal } & \multirow{2}{*}{ Rata } \\
\cline { 2 - 5 } & Soal 1 & Soal 2 & Soal 3 & Soal & \\
\hline 37 Siswa & & & & & \\
& 1,1 & 3,7 & 10,5 & 14,2 & 7,3 \\
\hline Nilai Mak & 10 & 20 & 30 & 40 & \multirow{2}{*}{100} \\
& & & & & \\
\hline Tertinggi & 2 & 10 & 18 & 24 & 13,5 \\
\hline Terendah & 0 & 0 & 3 & 8 & 2.5 \\
\hline Ketuntasan & & \multicolumn{2}{|c|}{28 Peserta Didik } \\
\hline
\end{tabular}

\section{DAFTAR PUSTAKA}

Amrin, T.M. (2013). Manajemen Pendidikan. Yogyakarta: UNY Press.

Arikunto, S. (2017). Pengembangan Instrumen Penelitian dan Penilaian Program. Yogyakarta: Pustaka Pelajar.

Arsyad, A. (2011). Media Pembelajaran. Jakarta: PT Raja Grafindo Persada

Bilfaqih, Yusuf dan M. Nur Qomarudin. (2015: 1). Pembelajaran Daring Panduan Berstandar Pengembangan Pembelajaran Daring untuk Pendidikan dan Pelatihan. Yogyakarta: Deepublish.

Daryanto, (2014). Pendekatan Pembelajaran Saintifik Kurikulum 2013. Yogyakarta: Gava Media.

Dewi, W. A. F. (2020). Dampak Covid-19 terhadap Implementasi Pembelajaran Daring di Sekolah Dasar. Edukatif:

Djamarah, Syaiful Bahri dan Aswan Zain. (2010) Strategi Belajar Mengajar. Jakarta. Rineka Cipta.

Jurnal Ilmu Pendidikan, 2(1), 55-61. Fadillah, M. (2014). Implementasi Kurikulum 2013 dalam Pembelajaran SD/MI, SMP/MTs, \& SMA/MA.Yogyakarta: Ar-Ruzz Media.

Gilbert, \& Jones, M. G. (2001). E-Learning is e-normous. Electric Perspectives, 26(3), 66-82.

Hamalik, O. (2017). Kurikulum dan Pembelajaran. Jakarta: Bumi Aksara. . (2017). Dasar-Dasar Pengembangan Kurikulum. Bandung: PT Remaja Rosdakarya. 
pada tanggal 20 April 2020, pukul 14.00 WIB).

\%20pkn\&f=false (diakses pada tanggal 21 April 2020, pukul 09.00 WIB).

Kemendikbud. (2013). Permendikbud Nomor 81a Tahun 2013 tentang Implementasi Kurikulum. Jakarta: Menteri Pendidikan dan Kebudayaan Republik Indonesia Kemendikbud. (2016).

Permendikbud Nomor 22 Tahun 2016 tentang Standard Proses Pendidikan Dasar dan Menengah. Jakarta: Menteri Pendidikan dan Kebudayaan Republik Indonesia Khan, Badrul. (2005).

Managing E-learning: Design, Delivery, Implementation and Evaluation. Hershey, PA: Information Science Publishing.

Majib, A dan Rochman, C. (2014). Pendekatan Ilmiah dalam Implementasi Kurikulum 2013. Bandung: PT Remaja Rosdakarya.

Majid, A. (2014). Implementasi Kurikulum 2013. Bandung: Interes Media.

Menteri Pendidikan. (2020). Surat Edaran Nomor 3 Tahun 2020 Tentang Pelaksanaan Pendidikan dalam Masa Darurat CoronaVirus (COVID-19).

Mulyasa, E. (2002). Kurikulum berbasis kompetensi. Bandung: Rosda Karya. . (2014). Pengembangan dan Implementasi kurikulum 2013. Bandung: Remaja Rosdakarya.

Munadi, Yudhi. (2013). Media Pembelajaran, Sebuah Pendekatan Baru. Jakarta: Gaung Persada Press Muzamiroh, L. M. (2013). Kupas Tuntas Kurikulum 2013. Jakarta: Kata Pena Nakayama

M, Yamamoto H, \& S. R. (2007). The Impact of Learner Characterics on Learning Performance in Hybrid Courses among Japanese Students. Elektronic Journal E-Learning, Vol.5(3).1.

Nasution, S. (2008). Asas-Asas Kurikulum. Jakarta: Bumi Aksara, Edisi Kedua. Pambudi, A. F. (2014). Analisis Spektrum Gaya Mengajar Divergendalam Implementasi Kurikulum 2013. Jurnal Pendidikan Jasmani Indonesia, 10(2).

Pemerintah Indonesia. (2003). Undang-Undang RI Nomor 20 Tahun 2003 tentang Sistem Pendidikan Nasional Bab I Pasal 1 (ayat 1). Jakarta: Sekretariat Negara

Purwanto, A., Pramono, R., Asbari, M., Hyun, C. C., Wijayanti, L. M., \& Putri, R. S. (2020). Studi Eksploratif Dampak Pandemi COVID-19 Terhadap Proses Pembelajaran Online di Sekolah Dasar. EduPsyCouns: Journal of Education, Psychology and Counseling, 2(1), 1-12.

Qomarrullah, Rif'iy. 2014. "Model Aktivitas Belajar Gerak Berbasis Permainan Sebagai Materi Ajar Pendidikan Jasmani (Penelitian Pengembangan Pada Siswa Kelas I Sekolah Dasar).” Indonesian Journal of Sports Science 1 (1): 76-88.

Rahayu, Ega,T. (2013). Strategi Pembelajaran Pendidikan Jasmani. Bandung: Alfabeta. Rohmah. (2016). Konsep E-Learning Dan Aplikasinya Pada Lembaga Pendidikan Islam. Jakarta: AnNur.

Sagala, S. (2010). Kemampuan Professional Guru dan Tenaga Kependidikan. Bandung: Alfabet.

Saryono \& Rithaudin, A. (2011). Meta Analisis Pengaruh Pembelajaran Pendekatan Taktik (TGFU) Terhadap Pengembangan Aspek Kognitif Siswa dalam Pendidikan Jasmani. Jurnal Pendidikan Jasmani Indonesia, 8.

Sudijono, A. (2011). Pengantar Evaluasi Pendidikan. Jakarta: PT Raja Grafindo

Sudjana, Nana. 2000. Dasar-dasar Proses Belajar Mengajar. Bandung: Sinar Baru Algensindo. 
2010. Dasar-Dasar Proses Belajar Mengajar. Bandung: Sinar Baru Algensindo

Sudjana, Nana \& Ahmad Rivai. 2001. Media Pengajaran. Bandung: Sinar Baru Algesindo

Persada Sudjana, N (2010). Dasar-dasar Proses Pembelajaran. Bandung: Sinar Baru

Sugiyono. (2017). Metode Penelitian Kuantitatif, Kualitatif, dan R\&D. Bandung: Alfabeta.

Suherman, W.S. (2018). Kurikulum Pendidikan Jasmani dari Teori hingga Evaluasi Kurikulum. Depok : PT Rajagrafindo Persada.

Utama, A. B. (2011). Pembentukan Karakter Anak Melalui Aktivitas BermainDalam Pendidikan Jasmani. Jurnal pendidikan jasmani indonesia, 8(1).

WHO. (2020). Pertanyaan dan Jawaban Terkait Coronavirus. Diakses 14 Juli 2020, dari https://www.who.int/indonesia/news/novel-coronavirus/qa-for_public

Yurianto, Ahmad, Bambang Wibowo, K. P. (2020). Pedoman Pencegahan dan Pengendalian Coronavirus Disease (Covid-19) (M. I. Listiana Azizah, Adistikah Aqmarina (ed.)). 